\title{
вмJ Global Health Quagmire of epidemic disease outbreaks reporting in Nigeria
}

\author{
Semeeh Akinwale Omoleke, ${ }^{1}$ Olumide Ajibola, ${ }^{2}$ Jubilee Odunola Ajiboye, ${ }^{3}$ \\ Rilwan Olaolu Raji ${ }^{4}$
}

To cite: Omoleke SA, Ajibola 0, Ajiboye J0, et al. Quagmire of epidemic disease outbreaks reporting in Nigeria. BMJ Glob Health 2018;3:e000659. doi:10.1136/ bmjgh-2017-000659

Handling editor Seye Abimbola

Received 27 November 2017 Revised 25 January 2018 Accepted 30 January 2018

\section{Check for updates}

${ }^{1}$ Immunisation, Vaccines and Emergencies Unit, World Health Organisation, Birnin Kebbi, Kebbi State Field Office, Nigeria ${ }^{2}$ Department of Microbiology, Federal University, Birnin Kebbi, Kebbi State, Nigeria

${ }^{3}$ Internship, World Health Organisation, Birnin Kebbi, Kebbi State Field Office, Nigeria ${ }^{4}$ Immunisation, Vaccines and Emergencies Unit, World Health Organisation, Lafia, Nasarawa State Field Office, Nigeria

Correspondence to Dr Semeeh Akinwale Omoleke; omolekes@who.int

\section{INTRODUCTION}

Epidemic disease outbreaks are typically regarded as newsworthy events, monitored and reported by both national and international media. Traditionally, government are primarily responsible for outbreak response and communication to the press as well as stakeholders. This norm often makes other sources of information unacceptable to the government as a reliable information channel to elicit appropriate public health action(s). In this commentary, based on evidence in the literature and insight from our professional experience in the course of public health practice in West Africa, we detail reasons why governments (using Nigeria as an example), may conceal or under-report outbreaks, and we also suggest pragmatic solutions to address this challenge.

\section{HEALTH SYSTEM CAPACITY AND INTERNATIONAL STIGMATISATION/ISOLATION}

Nigeria, with over 170 million people, has experienced many disease outbreaks both in the past, and more recently with, Lassa fever and Meningitis outbreaks and an outbreak of Ebola 3 years ago. Nigeria like other West African countries has a long history of concealing or under-reporting disease outbreaks for reasons which may be due to political, socioeconomic or health system factors. ${ }^{12}$ In 1996, Nigeria experienced an epidemic of cerebrospinal meningitis (CSM) type A that swept across Northern Nigeria and claimed at least 11700 lives. In response to the CSM outbreak in Nigeria, the Saudi Arabian government issued a ban preventing Nigerian pilgrims from entering Mecca to observe the Hajj (Muslim) pilgrimage. ${ }^{23}$

Restrictive immigration policy during outbreaks is further aggravated by suboptimal healthcare services, weak surveillance and inadequate diagnostic laboratories to promptly detect, report and monitor outbreaks. These
Summary box

Epidemic disease outbreaks are typically regarded as newsworthy events monitored by national and international media. Traditionally, governments are primarily responsible for outbreak response and communication to the press as well as stakeholders. But in our experience, governments, especially in West Africa (including Nigeria), are sometimes unwilling to rapidly report outbreaks or under-report the scale of the outbreaks.

- We identified reasons that could explain this unfortunate practice: weak health system capacity and fear of international isolation/stigmatisation; poor prioritisation of health and health emergencies in the context of economic downturn; weak leadership and accountability and knowledge deficit on outbreaks and management approach.

- Based on our experience in Nigeria, we propose that public health authorities, with the support of WHO and UNICEF of country offices, should strengthen engagement with political office holders and orientate them on the importance of reporting outbreaks and timely response, advocate for better funding (for clinical and laboratory surveillance as well as response) and address corruption by instituting and enforcing monitoring and accountability for public health officers.

- The polio legacy plan in Nigeria should be targeted at strengthening Integrated Disease Surveillance and Response (IDSR). The robust personnel strength, capacity built, network of laboratories as well as the evolving collaboration between conventional (formal) and alternative (informal) reporting system should be optimised and diversified to effectively detect, report, respond to and monitor disease outbreaks and other health emergencies.

clear gaps in the Nigerian health sector impede rapid containment of outbreaks. In response to the perceived threat and weak containment capacity, neighbouring African countries and western nations that usually receive Nigerian visitors often quickly revise immigration policies, thus stimulating various political and socioeconomic responses. ${ }^{4-6}$ 
COMPETING PRIORITY IN THE FACE OF ECONOMIC DOWN TURN

Reluctance by public health authorities to rapidly confirm and respond to outbreaks in view of the high cost implication is another factor that makes public health authorities conceal outbreaks. The recent CSM outbreak in Nigeria (2017) demonstrated an example of why African governments conceal outbreaks due to cost implications. The 2017 CSM outbreak in Nigeria caused by type C Neisseria meningitidis led to prioritisation of intervention, specifically reactive vaccination was based on severity of outbreak, using epidemic thresholds in order to reduce vaccination costs. Reactive vaccination, although cost-effective was implemented late which led to loss of about 493 lives in the country. Kebbi State in Northern Nigeria recently reported an outbreak of measles, but the approach of the government was to carry out limited reactive vaccination in selected administrative wards which cost the government approximately US $\$ 19048$ for a single phase of vaccination.

Such paltry sum spent on a few administrative wards was difficult for state governments to prioritise outbreak response given other competing priorities (salaries, social infrastructure) owing to economic recession, and drop in revenue from crude oil sales the country is currently experiencing. The situation is worrisome given that backlog of workers' salaries and pensions are being owed by most of the state governments in Nigeria. ${ }^{7}$ In addition, one of the fundamental principles of outbreak response is to innovate and implement strategies that will prevent a recurrence of the outbreak. This implies the need for additional funds which the government is usually unwilling to spend. Cost implications of disease outbreaks could be overwhelming depending on disease type (particularly diseases with high transmission rate, eg, Ebola, Meningitis, Avian Influenza H1N1) and population of affected individuals whether children, elderly or across all age groups.

\section{WEAK LEADERSHIP CRISIS AND POOR KNOWLEDGE OF OUTBREAK MANAGEMENT}

Poor knowledge of infectious diseases by political office holders, corruption, limited financial resources, unwillingness to strengthen routine surveillance system and poor management of funds by health ministry continue to increase costs of dealing with disease outbreaks in Nigeria. In addition to these challenges is the slow response of the international community in meeting resource mobilisation requirement (human and financial resources) to combat such outbreaks as seen in the Ebola outbreak in the West African subregion -in Guinea, Liberia and Sierra Leone. We acknowledge the fact that the primary responsibilities of resource mobilisation (human and material) rest on the governments at all levels in the affected countries, but they often fail to live up to expectations due to some of the aforementioned reasons. On the other hand, recent guidelines and regulations on emerging and re-emerging infectious diseases did not sufficiently take into account the disproportionate social and economic losses incurred by low-income and middle-income countries when they report outbreaks. ${ }^{4}$

Another important angle to poor reporting of public health outbreaks is limited understanding of the implications. Early disease notification, reporting, investigation and response reduces mortality and morbidity and creates wider socioeconomic cost on the affected country and also has negative global impacts, given the present interconnectedness of the world. ${ }^{4}$ A vivid programmatic finding before now was the misconception about acute flaccid paralysis (AFP), which is a 'syndromic diagnosis' and often misconstrued as being pathognomonic of Wild Polio Virus. We are aware of unwritten instructions (from informal interactions with health workers) not to report AFP for fear of it being a WPV incident. When health workers report AFP (acting contrary to instruction), they face rebuke from higher authorities. This is however fast changing, with better engagement of all stakeholders including health workers and traditional institutions, as more AFP cases are being reported in Nigeria beyond the minimum requirement. ${ }^{8}$

A similar misunderstanding was recently exemplified in the recent outbreak of type C CSM in a state in Northern Nigeria, where the Governor of one of the most affected states asserted that the outbreak was a result of 'people's refusal to stop their nefarious activities and God's way of showing his anger against Nigerians for turning their backs on him'. ${ }^{9}$ The ignorance exhibited by such highly placed political leader could send wrong signals, and consequently discourage health workers at the operational level (clinics and communities) from reporting suspected cases, some of which may actually turn out to be an outbreak indeed. Although corrective action had been taken by partners led by WHO Coordinator and supported by traditional institution (Emirs) in the affected state through advocacy and sensitisation of the Executive Governor, who hitherto had demonstrated sheer ignorance. This underscores the need to routinely conduct advocacy and sensitisation of political leaders on surveillance, emergencies and response.

\section{WEAK ACCOUNTABILITY IN DISEASE OUTBREAK MANAGEMENT}

Outbreaks with pandemic potentials such as Ebola, yellow fever, CSM and cholera may remain unreported or under-reported often as a result of the fear of unwarranted reactions that can affect travel and trade; cause international isolation and stigmatisation, which may have grave socioeconomic implications on affected countries. ${ }^{46710}$ Nigerian technocrats may be averse to reporting disease outbreaks, especially when funds had been allocated for outbreak prevention campaigns, and had not been implemented. The fear of impending queries and pressure from international donors that may lead to audit on donor funds expenditure may compel public health authorities and political office holders to leave outbreaks unreported or preferably, quietly managed. 
The occurrence of disease outbreaks also reveals flaws and glitches in existing social infrastructure and public health policies, which government officials usually find humiliating. More importantly, revealing these infrastructural deficits mount pressure on the state governments to scale up social infrastructural development programmes. Hence, concealing the nature and magnitude of a disease outbreak becomes the easiest way for West African Governments to secure their political positions and improve their chances of re-election. African political office holders, unlike public health officials, are not driven by motivation to contribute to global health equity but rather make decisions motivated by their desires to elongate their grip on power.

\section{WAY FORWARD}

The ongoing polio legacy plan in Nigeria should be targeted at strengthening integrated disease surveillance and response. Currently, the polio eradication programme is being used to support integrated disease surveillance and response in Nigeria. For instance, WHO personnel working on the polio programme were deployed to the field and provided support at all levelsnational to the lowest operational and political jurisdiction in Nigeria (ie, administrative wards) during the CSM, Lassa and Ebola outbreaks in the last 3 years. These personnel provided technical support to the conventional (formal) surveillance system as well as an informal community surveillance network. The community-based system established a link with conventional reporting channels, and this has improved transparency. This innovative collaboration has recently improved disease detection, notification and prompt investigation as seen in polio surveillance in Nigeria. While the system is still evolving in supporting Integrated Disease Surveillance and Response (IDSR), the results are promising if well harnessed.

Based on our experience, public health authorities within countries, with the support of their WHO and UNICEF country offices, should strengthen engagement with political office holders and properly orientate them on the importance of reporting outbreaks and timely response, advocating for better funding (of clinical and laboratory surveillance as well as response) and addressing corruption by instituting and enforcing monitoring and accountability for public health officers at all levels of government in Nigeria (Federal, state and local government). Strong political will and sustained engagement with political office holders by WHO and UNICEF (globally and within countries) will be required to achieve these proposals.

Contributors SAO conceived and designed the framework of the paper, participated in the writing and critically reviewed the paper; $O A$ participated in the writing of the paper and critically reviewed the manuscript; JOA conducted literature search and participated in the writing of the manuscript while ROR contributed to literature search and participated in the writing of the manuscript. All authors read and approved the final draft of the manuscript.

Funding This research received no specific grant from any funding agency in the public, commercial or not-for-profit sectors.

Competing interests None declared.

Patient consent Not required.

Provenance and peer review Not commissioned; externally peer reviewed.

Open Access This is an Open Access article distributed in accordance with the Creative Commons Attribution Non Commercial (CC BY-NC 4.0) license, which permits others to distribute, remix, adapt, build upon this work non-commercially, and license their derivative works on different terms, provided the original work is properly cited and the use is non-commercial. See: http://creativecommons.org/ licenses/by-nc/4.0/

(C) Article author(s) (or their employer(s) unless otherwise stated in the text of the article) 2018. All rights reserved. No commercial use is permitted unless otherwise expressly granted.

\section{REFERENCES}

1. Cash RA, Narasimhan V. Impediments to global surveillance of infectious diseases: consequences of open reporting in a global economy. Bull World Health Organ 2000;78:1358-67.

2. Ejembi CL, Renne EP, Adamu HA. The politics of the 1996 cerebrospinal meningitis epidemic in Nigeria. Africa 1998;68:118-34.

3. International Federation of Red Cross and Red Crescent society. Emergency Plan of Action (EPOA) Nigeria: meningitis. 2017. www. ifrc.org (accessed 27 Jun 2017).

4. Omoleke SA, Mohammed I, Saidu Y. Ebola viral disease in West Africa: a threat to global health, economy and political stability. J Public Health Africa 2016;7 http://www.ncbi.nlm.nih.gov/pmc/ articles/PMC5349256/

5. The World Bank. 2014-2015 West Africa Ebola Crisis. http://www. worldbank.org/en/topic/macroeconomics/publication/2014-2015west-africa-ebola-crisis-impact-update 2015 (accessed 3 Sep 2017)

6. Bali S, Stewart KA, Pate MA. Long shadow of fear in an epidemic: fearonomic effects of Ebola on the private sector in Nigeria. BMJ Glob Health 2016;1:e000111.

7. Governor Abdulaziz Yari. Governors to offset workers' salary backlog with Paris Club refunds. 2017. https://www.vanguardngr.com/2017/ 06/governors-offset-workers-salary-backlog-paris-club-refunds/

8. Hamisu AW, Johnson TM, Craig K, et al. Sensitivity of Acute Flaccid Paraysis in Nigeria (2006-2015). Journal of Infectious Disease and Treatment 2016;2:13.

9. Adekunle. God sent Type C Meningitis to punish Nigerians for their sins - Gov. Yari. Vanguard Newspapers 2017 http://www. vanguardngr.com/2017/04/god-sent-type-c-meningitis-punishnigerians-sins-gov-yari/ (accessed 28 Jun 2017).

10. Rodier DLH and GR. Global surveillance of communicable diseases. Emerging Infectious Disease journal 1998;4 https://wwwnc.cdc.gov/ eid/article/4/3/98-0305_article 